\title{
Juha Rikama
}

\section{Selitysvoimaisesta kontekstoinnista}

Liisa Steinby käsittelee Avaimessa 2/2014 julkaistussa artikkelissaan "Elliptinen synteesi: (sosiaalihistoriallisen) kirjallisuushistorian kirjoittamisen vaikeudesta" saksalaisen kirjallisuushistorian vaiheita. Hänen mukaansa niistä ilmenee siirtymä tekstiautonomisesta historiasta kohti kontekstoivaa historiankirjoitusta mutta samalla myös jatkuvaa huojuntaa näiden lähestymistapojen välillä. Sama on hänen mukaansa havaittavissa myös suomalaisten kirjallisuushistorioiden kehityksessä. Pyrkimys kohti yhä laajempaa kontekstointia perustuu jatkuvasti voimistuneeseen ajatukseen, että tutkittavan asian voi ymmärtää paremmin kontekstoimalla sen ympäröivään todellisuuteen.

Tämä olettamus muistuttaa vapaamielistä käsitystä, että maailmassa kaikki vaikuttaa kaikkeen, että kaikki maailman osat ovat yhteydessä toisiinsa. Tämä visio ei kuitenkaan paljoa auta selittämään ja ymmärtämään pyrkivää tutkimusta: juuri sen pohjalta syntyy usein vain löysää mieleenjohtumista, essehtimistä. Järkevän, uskottaviin tuloksiin johtavan kontekstoinnin perimmäisiä ehtoja ei ole vielä pohdittu tarpeeksi. Tämän toteaa Steinbykin moittiessaan uusia suomalaisia kirjallisuushistorioita vain riittävän perusteellisen reflektoinnin puutteesta.

Kontekstoija joutuu tosiasiassa aina suorittamaan valintaa päästäkseen johonkin uskottavaan lopputulokseen. Reflektointia on juuri se, että etsii ja esittää riittävät perusteet valinnalle: mihin teksti kannattaa kontekstoida, jotta kontekstointi tuottaisi todellista tietoa tekstistä. On liian ylimalkaista sanoa, että kaunokirjallisuuden kontekstointi täytyy kohdistaa tekstiä ympäröivään yhteiskunnalliseen elämään. Seuraavassa esitän tähän määrittelyyn täsmennyksen, joka mielestäni lisää olennaisesti kontekstointimenettelyn selitysvoimaa.

Akateemikot George Henrik von Wright (1968) ja Erik Allardt (1968) pohtivat jo 1960-luvulla erilaisia selittämisen lajeja ja siinä yhteydessä myös järkevän kontekstoinnin ehtoja. Yhtenä selittämisen lajina he pitivät finalistista selittämistä, joka ei tutki kausaalisia vaan loogisia yhteyksiä ilmiötä ja sen semanttista ympäristöä koskevien lausumien välillä. Syy-seuraus-suhteen asemesta sen selitysmallina on peruste ja siitä loogisesti seuraava johtopäätös. Perusteiden kokonaisuutta mallissa kutsutaan motiivitaustaksi.

Samoihin aikoihin alettiin korostaa finalistisen mallin soveltuvuutta aatehistorialliseen kirjallisuudentutkimukseen. Mallia oli esimerkiksi kirjallisuushistoriassa käytetty iät ja ajat, mutta mallin täsmällinen analyysi, siis reflektointi, puuttui. 1960-luvun 
lopussa kirjoitin Kirjallisuudentutkijoiden Seuran vuosikirjaan artikkelin "Finalistinen selittäminen kirjallisuustieteessä" (Rikama 1969). Siinä esitin seuraavaa. Finalistisiin selityksiin pyrkivässä kirjallisuudentutkimuksessa, jonka kohteena on yksittäinen teos, voidaan erottaa seuraavat kolme tutkimusvaihetta, jotka nähdäkseni vastaavat melko hyvin myös käytännön työvaiheita: 1) teoksen identifiointi, so. sen oman merkitysjärjestelmän selvittäminen ja kuvaaminen, 2) teosta varhaisempaan kirjailijan semanttiseen ympäristöön perehtyminen, ja 3) kirjailijan semanttisen ympäristön ja teoksen merkitysjärjestelmän välisten käsitteellisten yhteyksien paljastaminen. Finalistisen selityksen antaminen edellyttää siis tietoa toisaalta selitettävästä teoksesta, toisaalta kirjailijan semanttisesta ympäristöstä. Lisäksi se edellyttää analyyttista suoritusta: selittävän ja selitettävän välisten käsitteellisten riippuvuussuhteiden paljastamista loogisen analyysin ja päättelyn avulla.

Artikkelini reflektoinnin päätulos oli siis se, että kontekstointi kannattaa suorittaa vain sellaisiin todellisuuden osiin eli niitä koskeviin lausumiin, joilla on käsiteanalyysillä todistettava merkitysyhteys kontekstoitavaan tekstiin. Tällaisen merkitysyhteyden osoittaminen vaatii huolellista ja monivaiheista kaunokirjallisen tekstin ja sen kontekstointikohteen merkitysanalyysiä.

Kirjailijan semanttinen ympäristö koostuu hänen tuntemistaan merkityksistä ja merkitysjärjestelmistä. Koska ennakolta on mahdotonta sanoa, mitkä niistä motivoivat loogisesti teoksen merkityksiä, ne olisi teoksen motiivitaustaa etsittäessä periaatteessa tunnettava kaikki. Käytännössä kirjailijan tajunnan ja piilotajunnan historian kirjoittaminen on mahdoton tehtävä. Siksi onkin tyydyttävä vaatimattomampaan tavoitteeseen, nimittäin niiden merkitysten tutkimiseen, jotka ennen teoksen kirjoittamista ovat todennäköisesti olleet kirjailijan tuntemia ja joista on saatavissa luotettavaa tietoa. Tällaista merkitysaineistoa on ainakin kaikki se, mitä kirjailija on lukenut, kuullut, kirjoittanut tai sanonut.

Se käsitys kirjallisuustieteellisestä selittämisestä, jota edelleen haluan puolustaa, perustuu näkemykseen, että kirjailijan kokemuspiiriin ja hänen teoksiinsa sisältyvät merkitykset muodostavat semanttisen kokonaisuuden, jonka osia voidaan tarkastella suhteessa kokonaisuuden muihin osiin sen seikan selvittämiseksi, mitkä osat ovat käsitteellisesti riippuvaisia toisistaan. Se, mikä tässä kokonaisuudessa valitaan selityksen kohteeksi, määräytyy tutkimuksen yleisemmistä, selitystavasta riippumattomista tavoitteista. Jos pyritään selittämään kirjailijan yksityistä teosta, on etsittävä sen yhteyksiä hänen semanttisen todellisuutensa teoksen kirjoittamista varhaisempiin osiin, esimerkiksi hänen kirjeisiinsä ja aikaisempiin teoksiinsa; ne osat, joihin yhteyksiä löytyy, muodostavat teosta selittävän motiivitaustan. Selityksen kohteeksi voidaan puolestaan valita myös jokin tämän motiivitaustan osa, esimerkiksi kirjailijan kirjeet, ja yrittää etsiä motiivitaustaa sille. Samaa selitysmallia voidaan käyttää myös selitettäessä kirjailijan 
koko tuotantoa tai jonkin ajanjakson kirjallisuutta yleensä, motiivitausta muodostuu näissä tapauksissa vain laajemmaksi.

Finalistista mallia käytetään ehkä eniten historiantutkimuksessa. Pohtiessaan, miten kirjallisuudentutkimusta voitaisiin yleistajuistaa Leena Kaakinen $(2014,72)$ on ottanut vertailukohdaksi uudet, suurta yleisöäkin kiinnostavat historiantutkimukset, kuten Mirkka Lappalaisen, Markku Jokisipilän, Ville Kivimäen ja Teemu Keskisarjan teokset. Hänen mukaansa kiinnostus sekä historian- että kirjallisuudentutkimusta kohtaan lisääntyy sitä mukaa, kuin ne pystyvät osoittamaan uusia, ennen huomaamattomia yhteyksiä todellisuuden eri osien välillä.

Historian- ja kirjallisuudentutkimus ovat tässä suhteessa samassa asemassa. Ne molemmat toimivat sellaisessa todellisuudessa, jota voi kutsua semiosfääriksi eli maailman semanttiseksi kokonaiskentäksi, ja molemmat paljastavat uusia merkitysyhteyksiä semanttisen kentän eri osien välillä.

Suuren yleisön kiinnostus myös kirjallisuudentutkimusta kohtaan lisääntyy sitä mukaa, kun tutkimus pystyy osoittamaan merkitysyhteyksiä historiallis-yhteiskunnallisen todellisuuden ja kirjailijoiden teosten ilmaisemien elämänkokemusten ja -käsitysten välillä. Jotta tämä tulkintatehtävä onnistuisi, kirjallisuudentutkijalta (ja kirjallisuuskriitikolta) vaaditaan laajaa semanttisen kokonaiskentän tuntemusta ja siinä vallitsevien merkitysyhteyksien ymmärtämiskykyä.

Voidaan väittää, että kaunokirjalliselle teokselle ei ole mahdollista koskaan löytää niin laajaa motiivitaustaa, että sen avulla annetut selitykset kattaisivat koko teoksen. Tämä saattaa pitää paikkansa, mutta ei merkitse periaatteellista estettä finalistisen selitystavan soveltamiselle käytännössä niin pitkälle kuin mahdollista. Vaihtoehdoksi jää: se selitetään mikä voidaan.

Jälkistrukturalismi yrittää torjua intersubjektiivisesti pätevän merkitysanalyysin mahdollisuuden väittämällä, että tutkijan konteksti määrää kokonaan sen, millaisia merkitysyhteyksiä hän pystyy havaitsemaan. Tämä tieteellistä realismia vastaan sotiva väite johtaa loppuun vietynä tutkimuksen anarkiaan ja samalla yhteisen maailman katoamiseen. Kaikkea tuloksellista tutkimusta, myös kirjallisuudentutkimusta, yhdistävä tekijä on nähdäkseni se, että se toimii sen pääolettamuksen pohjalta, että havaintojen ja merkitysanalyysien paljastamat seikat eivät ole olemassa tutkijan kontekstissa vaan tutkijasta riippumattomassa intersubjektiivisessa todellisuudessa, mikä seikka voidaan varmistaa vertaisryhmien kontrollilla.

\section{Lähteet}

Allardt, Erik 1968. Sosiologisista selityksistä. Helsingin yliopiston sosiologian laitoksen tutkimuksia 117. Helsinki: Helsingin yliopisto. 
Kaakinen, Leena 2014. Kirjallisuudentutkimuksen yleistajuistaminen - miten ja kenelle? Avain 1/2014, 69-73.

Rikama, Juha 1969. Finalistinen selittäminen kirjallisuustieteessä. Pertti Hallikainen (toim.), Kirjallisuudentutkijain Seuran vuosikirja 24. Helsinki: KTS, 21-34.

Steinby, Liisa 2014. Elliptinen synteesi. (Sosiaalihistoriallisen) kirjallisuushistorian kirjoittamisen vaikeudesta. Avain 2/2014, 8-20.

von Wright, Georg Henrik 1968. Historiallisista selityksistä. Suom. Tauno Nyberg. Suomen Akatemia puhuu. Helsinki: WSOY, 179-200. 